Marketing i Zarządzanie

nr 3 (44) 2016, s. 197-206

DOI: $10.18276 / \mathrm{miz} .2016 .44-18$ ISSN: 2450-775X | http://wnus.edu.pl/pl/miz/

\title{
Grzegorz Szymański
}

Politechnika Łódzka

Wydział Organizacji i Zarządzania

e-mail: grzegorz.szymanski@p.lodz.pl

\section{Cechy e-klientów istotną determinantą rozwoju branży RTVIAGD sektora e-commerce}

Kod JEL: L81

Słowa kluczowe: e-klient, branża RTV/AGD, handel internetowy

Streszczenie. Klienci na rynku handlu elektronicznego bardzo często wykazują cechy homogeniczne, przykładowo wskazywanie niższych cen oraz wygody dokonywania zakupów w sieci jako najistotniejsze zalety e-commerce. Jednak w tak turbulentnym i konkurencyjnym otoczeniu coraz częściej menedżerowie internetowych platform handlowych powinni skupiać się na działaniach wyróżniających ich ofertę. Jedną z możliwości jest precyzyjne poznanie zachowań, zwyczajów i preferencji grupy docelowej. Dobór odpowiednich narzędzi komunikacji spersonalizowanych pod kątem cech demograficznych odbiorców oraz branży może okazać się znacznie skuteczniejszym działaniem niż tradycyjne formy marketingowe. Celem publikacji jest wskazanie różnic postrzegania i zachowań w sektorze e-commerce wśród klientów w zależności od podstawowych ich cech demograficznych. W analizie wykorzystano dostarczone przez firmę Opiniac dane z badania przeprowadzonego metodą ankiety internetowej z wykorzystaniem kwestionariusza ankiety.

\section{Wprowadzenie}

Rozwój handlu internetowego w Polsce charakteryzuje się dużą dynamiką, czego główną przyczyną są niższe koszty, wygoda oraz duża liczba dostępnych informacji. Większość istniejących raportów dotyczących sektora e-commerce 
analizuje cały segment, traktując go jako homogeniczny. Jednak duża konkurencyjność e-commerce wymusza na menedżerach wdrażanie innowacji (Pomykalski, Blażlak, 2014, s. 146), poszukiwanie nowych odbiorców oraz personalizację działań i kanałów komunikacyjnych, zwłaszcza w poszczególnych branżach. Kastomizacja determinuje wyodrębnienie grup docelowych odbiorców charakteryzujących się wspólnymi cechami. Celem niniejszego opracowania jest wskazanie różnic postrzegania i zachowań w sektorze e-commerce wśród klientów w zależności od podstawowych ich cech demograficznych. W analizie wykorzystano dostarczone przez firmę Opiniac dane, które były podstawą do stworzenia raportu efektu ROPO. Jako branżę do analizy wybrano najbardziej rozwijający się segment sektora e-commerce w Polsce w ostatnich latach, czyli RTV/AGD.

\section{Dynamiczny rozwój e-commerce w Polsce}

Historia rozwoju e-commerce pozwala na wyodrębnienie czterech etapów. Początkowo wszelkie działania i transakcje skupiały się wokół platform EDI (Electronic Data Interchange), dlatego jedna $\mathrm{z}$ pierwszych definicji określa e-handel jako współdzielenie się informacją przy użyciu różnych dostępnych technologii teleinformatycznych między organizacjami prowadzącymi transakcje wymiany dóbr i/lub usług (Sokol, 1989). Drugi etap rozpoczął się wraz z upublicznieniem internetu. Powstały pierwsze strony internetowe prezentujące produkty bez możliwości przeprowadzania transakcji elektronicznych. E-commerce definiuje w tym okresie Światowa Organizacja Handlu (WTO) jako produkcję, reklamę, sprzedaż i dystrybucję produktów przez sieci teleinformatyczne. Trzeci okres to upowszechnienie internetu, zwiększenie bezpieczeństwa transakcji, powstanie specjalizowanych firm logistycznych, rozwój sektora płatności internetowych oraz narzędzi i usług wspomagających działania w sektorze e-commerce. Wśród definicji z początku XXI wieku można znaleźć opracowania charakteryzujące e-handel jako ,zakup i sprzedaż informacji, towarów i usług za pomocą wyłącznie sieci komputerowych" (Wielki, 2000, s. 57) lub określano procesy kupna-sprzedaży wspierane przez urządzenia elektroniczne (Kotler, Armstrong, Saunders, Wong, 2002, s. 1055). Współcześnie można wskazać czwarty etap rozwoju e-commerce, do którego wcześniejsze definicje są wciąż aktualne, a który coraz częściej uwzględnia aspekt wykorzystania urządzeń mobilnych. M-commerce jest współcześnie najszybciej rozwijającą się gałęzią handlu internetowego, czego determinantami są: zwiększająca się liczba smartfonów i tabletów oraz niższe koszty użytkowania mobilnego internetu (Brzozowska-Woś, 2014, s. 8).

Popularność handlu internetowego jest współcześnie potwierdzona przez liczne raporty i badania rynku. Głównymi determinantami według polskich e-klientów są: dostępność całą dobę, brak konieczności osobistej wizyty w sklepie, łatwość dokonywania zakupu oraz atrakcyjniejsze ceny (Gemius, 2015, s. 35). Jednak różnice między wskazanymi czynnikami są uzależnione od danych 
demograficznych i ekonomicznych respondentów. Znacznie więcej mężczyzn (54\%) niż kobiet (40\%) docenia większą ilość informacji o produktach w internecie oraz możliwość kupienia rzeczy używanych lub kolekcjonerskich - uważa tak 44\% mężczyzn i tylko 35\% płci pięknej. Natomiast kobiety (86\%) uważają brak konieczności osobistej wizyty w sklepie jako jedną z najistotniejszych zalet e-zakupów, którą to opinię podziela $80 \%$ płci przeciwnej. Dysproporcje zauważane są także przy analizie zalet sektora e-commerce w zależności od wieku respondentów. Dostępność czasowa jest najważniejszą determinantą dla e-klientów w wieku 25-34 lata (93\%) oraz powyżej 50. roku życia (91\%), są to osoby przeważnie zaczynające pracę zawodową, poświęcające się karierze, które mają mało czasu na osobiste poszukiwania i zakup produktów. Różnice widać także przy analizie czynnika w postaci łatwości porównywania cen; pokolenia młodsze, które wychowywały się z internetem, w wieku 15-24 oraz 25-34 lata znacznie bardziej wartościują ten element (78\% i 84\%) niż generacja osób w przedziale 34-49 lat (68\%) oraz powyżej 50 lat (72\%), dla których to grup sama obsługa komputera i narzędzi internetowych może być już barierą.

Aż 31\% kupujących w sieci w UK wykorzystuje smartfony, w Niemczech i Hiszpanii to około 29\%, zaś w Polsce ten rynek to jedynie 8,3\% (Majchrzyk 2015). Ten sektor handlu internetowego także charakteryzuje się dużą wrażliwością na cechy klienta jak również wykorzystywane urządzenia. Polacy mobilnie najczęściej kupują jedzenie i napoje, natomiast wykorzystując komputery stacjonarne - głównie artykuły biurowe. Heterogeniczność wykazują także analizy uwzględniające kategorie produktowe, wśród których w ostatnim roku największe wzrosty popularności e-zakupów odnotowały branże RTV/AGD (wzrost z $52 \%$ do $56 \%$ ), telekomunikacja (z $48 \%$ do $51 \%$ ) oraz DIY (z 22\% do 27\%) (E-zakupy ..., 2015), (Omnichannel, 2014, s. 11). DIY (Do It Yourself) to specjalistyczna branża skupiająca wytwórców i sprzedawców m.in. narzędzi i elektronarzędzi, przyrządów, farb, oświetleń, wykończeń i ogrodnictwa itp. W mniej popularnych branżach działania komunikacyjne także wykorzystują popularne formy marketingowe, podążając za potencjalnymi klientami. Branża modowa jako jedna z pierwszych zauważyła potencjał mediów społecznościowych (Całka, Mróz-Gorgoń, 2014, s. 131), natomiast w internetowych zakupach grupowych dominują oferty turystyczne. Analizę badania przeprowadzono na branży RTV/AGD jako zyskującej w ostatnim roku największą popularność.

\section{Niejednolitość rynku e-commerce w badaniach}

Analizie poddano dane (raw data) uzyskane w ramach współpracy Wydziału Organizacji i Zarządzania Politechniki Łódzkiej z firmą Opiniac - autora i wydawcy raportu Efekt ROPO w segmentach polskiego e-commerce - 2015. Badanie przeprowadzono w czerwcu 2015 roku, wykorzystując kwestionariusz ankie- 
towy zawierający pytania zamknięte i jednowymiarowe skale rang oraz skale porządkowe. Badanie zostało przeprowadzone na grupie 13778 polskich użytkowników internetu, z czego 66\% stanowiły kobiety, co wskazuje na próbę niesymetryczną. Jednak jej liczebność pozwala na procentowe przedstawienie poszczególnych wyników podawane oddzielnie dla kobiet lub mężczyzn. Natomiast na potrzeby analizy porównawczej z innymi opracowaniami zastosowano wagi, pozwalające na statystyczne odzwierciedlenie wyników na populacji według danych GUS. W sumie uzyskano 14932 odpowiedzi, gdyż każdy respondent mógł odpowiadać w kilku kategoriach asortymentowych. Do analizy wybrano wyniki z branży RTV/AGD jako rozwijającej się najdynamiczniej w ostatnim roku w Polsce, gdzie uzyskano 7300 odpowiedzi, z czego 3374 respondentów dokonało zakupu w sklepie internetowym. Zastosowano celowy wygodny dobór próby, dystrybuując kwestionariusz ankiety na popularnym informacyjnym portalu internetowym (Onet.pl) oraz wielu portalach branżowych, zapewniając w ten sposób dostęp do klientów wybranych branż. Dla populacji internautów w Polsce na poziomie $35 \%$ (ok. 12250000 osób) uzyskano poziom ufności równy 0,99 oraz błąd szacunku 0,011 . Do oceny istnienia zależności zmiennych niezależnych od zmiennych zależnych wykorzystano test Chi-kwadrat z przyjętym dla wszystkich przypadków poziomem istotności równym 0,01 .

Jako zmienne zależne w badaniu wyznaczono wskaźniki uwzględniające: zakup w sklepie tradycyjnym i internetowym, rodzaj urządzenia, na którym dokonano zakupu w internecie, satysfakcję z zakupionego produktu, poziom zadowolenia z obsługi, szybkość realizacji zamówienia, możliwość polecenia sklepu znajomym oraz formę dokonania zakupu w przyszłości. Natomiast zmiennymi niezależnymi, względem których dokonano pomiaru współczynnika korelacji, zostały oznaczone cechy demograficzne respondentów: płeć oraz wiek.

Na rysunku 1 przedstawiono wyniki odpowiedzi na pytanie pierwsze, identyfikujące wykorzystywane urządzenia podczas zakupów na elektronicznych platformach handlowych branży RTV/AGD w podziale na grupy wiekowe. Uzyskano wartość statystyki Chi-kwadrat na poziomie 24,8 oraz $\mathrm{p}=0,005695$, czyli wartości mniejszej od przyjętego kryterium istotności 0,01 , co wskazuje na istnienie relacji między analizowanymi zmiennymi. Wybór urządzenia dokonywania e-zakupów jest skorelowany $\mathrm{z}$ wiekiem klienta. Widoczna jest zależność zwiększającej się popularności komputera stacjonarnego od wieku respondentów. Relacja ta wydaje się naturalnym zjawiskiem, osoby młodsze należące do generacji $\mathrm{Z}$ są dużo bardziej zaznajomione z nowoczesną technologią. Podobną zależność (Chi-kwadrat $=101,35, \mathrm{p}<0,00001)$ uzyskano na podstawie danych z pytania dotyczącego formy ostatniego zakupu (tab. 1), gdzie wraz z wiekiem e-klientów maleje liczba osób dokonujących zakupów w branży RTV/AGD w tradycyjnych sklepach. 


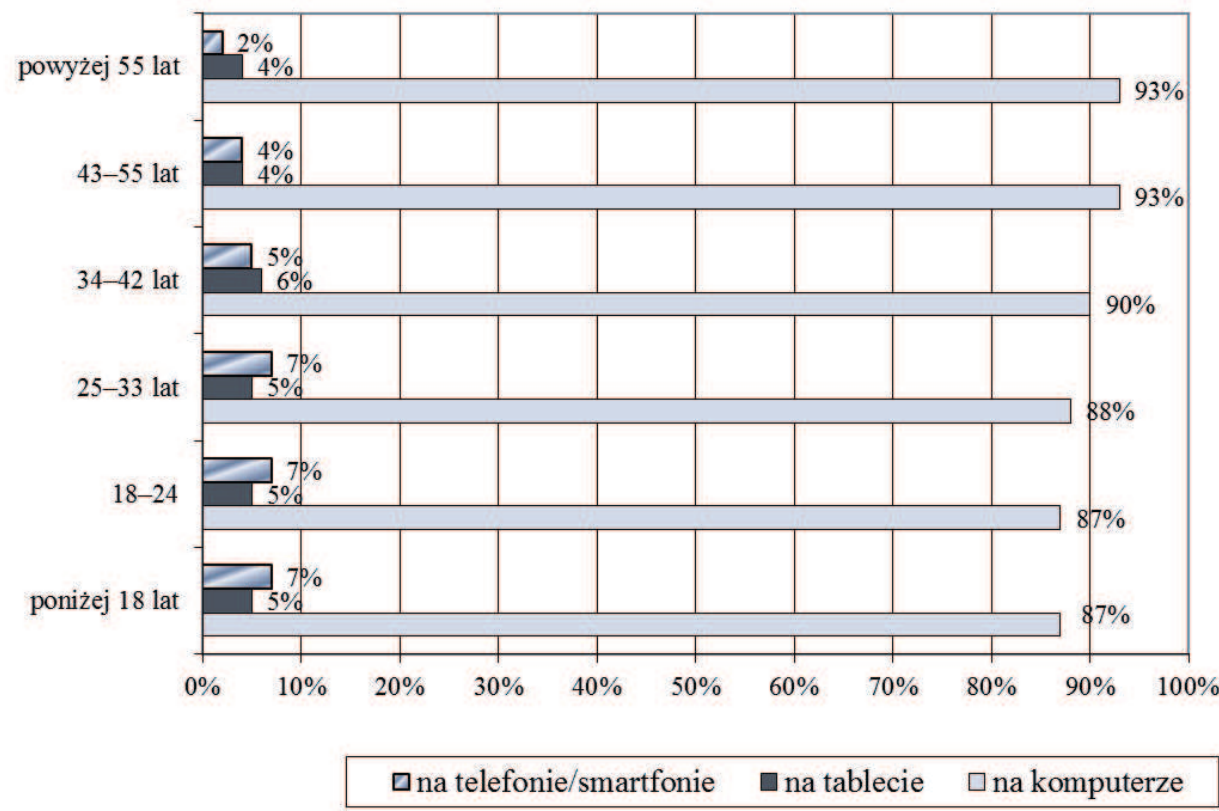

Rysunek 1. Popularność urządzeń wykorzystywanych do e-zakupów w branży RTV/AGD względem wieku e-klientów.

Źródło: opracowanie własne na podstawie danych dostarczonych przez firmę Opiniac wykorzystanych do raportu Efekt ROPO w segmentach polskiego e-commerce-2015.

W tabeli 1 przestawiano globalne wyniki odpowiedzi na poszczególne pytania w podziale na wiek respondentów. Pytania 4-6 w kwestionariuszu miały za zdanie zweryfikować poziom satysfakcji z zakupionego produktu (p4), poziom zadowolenia z obsługi klienta (p5) oraz szybkość realizacji zamówienia (p6). W każdym z tych pytań zastosowano skalę wagową od 1 do 5 , gdzie 1 oznaczało najniższy poziom, 5 zaś najwyższy. Analiza wyników dla tych trzech przypadków wskazała istnienie silnej korelacji między zmiennymi, dla średniej uzyskano współczynnik rang Spearmana równy odpowiednio 0,83 (p4/p5), 0,77 (p5/p6) oraz 0,94 (p4/p6). Powiązanie widać także przy poszczególnych wynikach, jednak, aby można było wskazać determinanty wpływające na zależności, należałoby przeprowadzić dodatkowe badanie pogłębiające. Niemniej uzyskane wartości średnie nie wskazują na istnienie korelacji $(\mathrm{p}=1)$ względem wieku respondentów. 
Tabela 1

Wyniki procentowe odpowiedzi na poszczególne pytania w podziale na przedziały wiekowe (w \%)

\begin{tabular}{|c|c|c|c|c|c|c|}
\hline & poniżej18 lat & 18-24 lat & $25-33$ lat & 34-42 lat & 43-55 lat & powyżej 55 lat \\
\hline \multicolumn{7}{|c|}{ Forma dokonania ostatniego zakupu } \\
\hline Sklep tradycyjny & 70 & 62 & 49 & 45 & 46 & 49 \\
\hline Sklep internetowy & 30 & 38 & 51 & 55 & 54 & 51 \\
\hline \multicolumn{7}{|c|}{ Poziom satysfakcji z zakupionego produktu (1-5), 1 - brak } \\
\hline 1 & 2 & 0 & 1 & 1 & 1 & 0 \\
\hline 2 & 0 & 1 & 1 & 1 & 1 & 1 \\
\hline 3 & 7 & 3 & 2 & 3 & 4 & 4 \\
\hline 4 & 18 & 20 & 22 & 22 & 21 & 25 \\
\hline 5 & 67 & 72 & 73 & 71 & 72 & 67 \\
\hline Nie wiem & 7 & 4 & 2 & 2 & 1 & 2 \\
\hline Średnia & 4,3 & 4,5 & 4,6 & 4,6 & 4,6 & 4,5 \\
\hline \multicolumn{7}{|c|}{ Poziom zadowolenia z obsługi klienta (1-5), 1 - bardzo niezadowolony } \\
\hline 1 & 0 & 0 & 1 & 1 & 1 & 1 \\
\hline 2 & 4 & 1 & 1 & $1 \%$ & $1 \%$ & $1 \%$ \\
\hline 3 & 7 & 6 & 5 & 5 & 6 & 7 \\
\hline 4 & 20 & 22 & 25 & 26 & 25 & 23 \\
\hline 5 & 64 & 67 & 66 & 65 & 66 & 66 \\
\hline Nie wiem & 5 & 4 & 2 & 2 & 2 & 2 \\
\hline Średnia & 4,3 & 4,4 & 4,5 & 4,5 & 4,5 & 4,5 \\
\hline \multicolumn{7}{|c|}{ Ocena szybkości realizacji zamówienia (1-5), 1 - zdecydowanie negatywna } \\
\hline 1 & 0 & 1 & 1 & 1 & 1 & 1 \\
\hline 2 & 0 & 1 & 1 & 2 & 1 & 1 \\
\hline 3 & 16 & 8 & 6 & 5 & 7 & 7 \\
\hline 4 & 32 & 20 & 18 & 23 & 23 & 22 \\
\hline 5 & 46 & 67 & 72 & 68 & 68 & 68 \\
\hline Nie wiem & 7 & 3 & 1 & 1 & 1 & 1 \\
\hline Średnia & 4,0 & 4,4 & 4,6 & 4,5 & 4,5 & 4,5 \\
\hline \multicolumn{7}{|c|}{ Chęć polecenia e-sklepu znajomym lub rodzinie (1-10), 1 - zdecydowanie nie polecę } \\
\hline 0 & 3 & 1 & 1 & 1 & 3 & 1 \\
\hline 1 & 1 & 1 & 0 & 1 & 0 & 2 \\
\hline 2 & 2 & 2 & 1 & 1 & 1 & 2 \\
\hline 3 & 2 & 2 & 2 & 2 & 2 & 4 \\
\hline 4 & 3 & 2 & 2 & 2 & 3 & 17 \\
\hline 5 & 14 & 10 & 11 & 12 & 14 & 7 \\
\hline 6 & 6 & 7 & 6 & 5 & 5 & 8 \\
\hline 7 & 13 & 10 & 10 & 9 & 9 & 14 \\
\hline 8 & 20 & 20 & 17 & 16 & 17 & 8 \\
\hline 9 & 13 & 14 & 13 & 13 & 12 & 34 \\
\hline 10 & 23 & 31 & 37 & 37 & 33 & 34 \\
\hline Średnia & 7,3 & 7,8 & 8,0 & 7,9 & 7,6 & 7,3 \\
\hline \multicolumn{7}{|c|}{ Wybór formy przy kolejnych zakupach w branży } \\
\hline Nie wiem & 29 & 21 & 24 & 31 & 36 & 38 \\
\hline $\begin{array}{l}\text { Sklep tradycyjny i inter- } \\
\text { netowy }\end{array}$ & 31 & 47 & 51 & 47 & 42 & 36 \\
\hline Tylko sklep internetowy & 3 & 3 & 6 & 6 & 5 & 6 \\
\hline Tylko sklep tradycyjny & 37 & 29 & 19 & 16 & 17 & 20 \\
\hline
\end{tabular}

Źródło: opracowanie własne na podstawie danych dostarczonych przez firmę Opiniac wykorzystanych do raportu Efekt ROPO w segmentach polskiego e-commerce-2015. 
Kolejne pytanie kwestionariusza „Na ile prawdopodobne jest, że poleci Pan/i ten sklep znajomym lub rodzinie?" umożliwiało ankietowanemu wskazanie odpowiedzi od 1 do 10, gdzie wartość 1 oznaczała zdecydowanie nie polecę, natomiast 10 - zdecydowanie polecę. Uzyskane wyniki kształtują się na poziomie średniej wartości od 7,3 do 8, co oznacza duże zadowolenie klientów z zakupów produktów branży RTV/AGD w internecie. Najmniej polecają je osoby w wieku poniżej 18 oraz powyżej 55 lat.

Ostatnie pytanie dotyczyło wyboru formy przyszłych zakupów w branży. Analiza statystyczna uzyskanych wyników wskazuje na istnienie korelacji między zmiennymi. Pytanie to zostało zadane wyłącznie osobom, które nie kupowały ostatnio produktów z branży RTV/AGD (5832 osoby). Warto zauważyć, że duża grupa respondentów jest niezdecydowana w wyborze konkretnej formy zakupów, a jednie około 5\% wskazało e-sklep jako przyszłą formę zakupową, przy $23 \%$ zwolenników tradycyjnego rozwiązania. Mimo że dynamika wzrostu internetowej sprzedaży w branży RTV/AGD jest w ostatnich latach największa, to uzyskane wyniki mogą wskazywać na jej regres. Wynikiem, który nie pokrywa się z powszechną opinią, że młode pokolenie zdecydowanie bardziej preferuje zakupy internetowe niż starsze generacje, jest dwukrotnie większa liczba osób w wieku powyżej 55 lat, niż poniżej 18 roku życia, które wskazały e-sklep jako miejsce następnych zakupów produktów RTV/AGD.

W tabeli 2 przedstawiono wyniki popularności urządzeń wykorzystywanych przez respondentów do zakupów w sektorze e-commerce $\mathrm{w}$ podziale także na płeć. Uzyskane wyniki potwierdzają, że bez względu na płeć najpopularniejszym współcześnie urządzeniem jest komputer. Mimo dynamicznego wzrostu m-commerce oraz eskalacji liczby kart SIM w Polsce, w sektorze e-commerce jedynie około 5\% internautów wykorzystuje tablet oraz telefon lub smartfon. Niewielkie różnice między uzyskanymi wynikami a innymi opracowaniami ( $87 \%$ - komputery, $23 \%$ - smartfon, $16 \%$ - tablet, zob. mShopper, 2015) wynikają z formy $\mathrm{i}$ rodzaju pytania $\mathrm{w}$ kwestionariuszu. W analizowanym badaniu zastosowano pytanie jednokrotnego wyboru sformułowane w postaci „Na jakim urządzeniu dokonał/a Pan/i ostatnio zakupu w sklepie internetowym sprzętu RTV/AGD?", natomiast inne opracowania określają znacznie szerszy zakres czasowy oraz możliwość wyboru kilku odpowiedzi (Czy dokonał/a Pan/i zakupu w ciągu ostatnich 6 miesięcy na tablecie/komputerze/smartfonie?). Jedyna znacząca różnica w wynikach uwzględniających płeć internautów została uzyskana wśród osób wykorzystujących smartfony, z których częściej zakupu dokonują mężczyźni (5,7\%) niż kobiety $(4,4 \%)$, co potwierdzają także inne raporty.

Natomiast istotna różnica zachowań występuje przy wyborze rodzaju sklepu: aż 54\% ankietowanych kobiet dokonało ostatniego zakupu produktu z branży RTV/AGD w sklepie tradycyjnym, które to rozwiązanie wybrało jedynie $44 \%$ ankietowanych mężczyzn. Trudno wskazać przyczyny takiej dysproporcji, być 
może wynika to z przywiązywania większej wagi do wyglądu przez kobiety i pragmatyczno-ekonomicznego podejścia mężczyzn. Nie odnotowano statystycznie istotnych różnic przy ocenie satysfakcji z produktu, zadowolenia z obsługi oraz szybkości realizacji zamówienia przez kobiety i mężczyzn. Wszystkie średnie wartości ukształtowały się na wysokim poziomie 4,5 w skali od 1 do 5 , co potwierdza także analiza wyników kolejnego pytania dotyczącego chęci polecenia znajomym i rodzinie sklepu internetowego.

Tabela 2

Popularność urządzeń wykorzystywanych do internetowych zakupów w zależności od płci e-klienta

\begin{tabular}{|l|c|c|c|c|}
\hline \multicolumn{1}{|c|}{ Cecha } & Kobiety & Mężczyźni & Kobiety & Mężczyźni \\
\hline Komputer & 1672 & 1372 & $90,7 \%$ & $89,6 \%$ \\
\hline Tablet & 91 & 72 & $4,9 \%$ & $4,7 \%$ \\
\hline Telefon/smartfon & 80 & 87 & $4,4 \%$ & $5,7 \%$ \\
\hline Sklep tradycyjny & 2223 & 1259 & $54,2 \%$ & $44,4 \%$ \\
\hline Sklep internetowy & 1876 & 1579 & $45,8 \%$ & $55,6 \%$ \\
\hline $\begin{array}{l}\text { Satysfakcja z zakupionego produktu } \\
\text { (1-5) }\end{array}$ & 1853 & 1553 & 4,6 & 4,5 \\
\hline $\begin{array}{l}\text { Poziom zadowolenia z obsługi } \\
\text { klienta (1-5) }\end{array}$ & 1822 & 1537 & 4,5 & 4,4 \\
\hline $\begin{array}{l}\text { Ocena szybkości realizacji zamówie- } \\
\text { nia (1-5) }\end{array}$ & 1806 & 1525 & 4,5 & 4,5 \\
\hline $\begin{array}{l}\text { Chęć polecenia e-sklepu znajomym } \\
\text { lub rodzinie (1-10) }\end{array}$ & 3985 & 2792 & 7,8 & 7,7 \\
\hline $\begin{array}{l}\text { Wybór e-sklepu przy kolejnych zaku- } \\
\text { pach }\end{array}$ & 189 & 96 & $5 \%$ & $7 \%$ \\
\hline $\begin{array}{l}\text { Wybór tradycyjnego sklepu przy ko- } \\
\text { lejnych zakupach }\end{array}$ & 961 & 238 & $23 \%$ & $16 \%$ \\
\hline
\end{tabular}

Źródło: opracowanie własne na podstawie danych dostarczonych przez firmę Opiniac wykorzystanych do raportu Efekt ROPO w segmentach polskiego e-commerce - 2015.

Ostatnie pytanie skierowane było do osób, które nie dokonały w ostatnim czasie zakupu produktu z branży RTV/AGD i identyfikowało preferowaną formę zakupu. Znacznie więcej (7pp.) kobiet niż mężczyzn deklaruje, że w przypadku dokonywania zakupu w przyszłości zdecydowałoby się wyłącznie na tradycyjny sklep, co potwierdza wcześniejsze wyniki, wskazujące zdecydowaną przewagę kobiet nad płcią przeciwną jako grupy preferującej zakupy w tradycyjnym sklepie. 


\section{Podsumowanie}

W Polsce istnieje około 20 tys. sklepów internetowych, branża RTV/AGD obejmuje $25 \%$ rynku, co stanowi 5 tys. konkurencyjnych ofert. Poznanie preferencji, zachowań oraz zwyczajów potencjalnych klientów pozwala na przygotowanie bardziej efektywnych strategii. Analiza wyników badania wskazuje na istotne różnice $\mathrm{w}$ wyborze sklepów tradycyjnych i internetowych wśród kobiet i mężczyzn, także w zależności od wieku e-klientów w branży RTV/AGD. Rozbieżności zaobserwowano również w ocenie szybkości realizacji zamówienia, gdzie ludzie młodzi (poniżej 18 lat) zdecydowanie gorzej ocenili ten element procesu zakupu internetowego niż pozostałe grupy wiekowe. Przedstawione wyniki analizy wskazują na istnienie istotnych różnic $\mathrm{w}$ zachowaniach poszczególnych grup respondentów, co powinno być wykorzystywane jako kluczowy element personalizacji przekazu marketingowego w sektorze e-commerce.

\section{Bibliografia}

Brzozowska-Woś, M. (2014). Kierunki rozwoju handlu elektronicznego. W: Przedsiębiorstwo we wspótczesnej gospodarce - teoria i praktyka, 1, 5-15.

Całka, A., Mróz-Gorgoń, B. (2014). Rola mediów społecznościowych w procesie komunikacji marketingowej - przykład marek modowych. Marketing i Rynek, 11, 123-131.

E-zakupy 2015 - raport Ceneo.pl i TNS Polska (20.05.2016). Pobrano z: pressroom.ceneo.pl/komunikaty-prasowe/e-zakupy-2015-raport-ceneo-pl-i-tns-polska.

Gemius (2015). E-commerce $w$ Polsce 2015. Gemius dla e-Commerce Polska. Pobrano z: https://www.gemius.pl/files/reports/E-commerce-w-Polsce-2015.pdf (12.04.2016).

Kotler, Ph., Armstrong, G., Saunders, J., Wong, V. (2002). Marketing. Podręcznik europejski. Warszawa: PWE.

Majchrzyk, Ł. (23.05.2016). M-commerce w Polsce i Europie w 2015 roku. Pobrano z: mobirank.p1/2015/10/18/m-commerce-polska-europa-2015-r.

mShopper (12.05.2016). Polacy na zakupach mobilnych. Pobrano z: http://ecommercepolska.pl/files/3214/2493/6753/raport_mShopper_Polacynazakupachmobilnych_luty2015_nowe.pdf.

Omnichannel Commerce. Raport z badania poziomu wielokanałowości $w$ wybranych branżach (2014). Pobrano z: http://raport.unitycommerce.pl/Raport_omnichannel_commerce.pdf.

Pomykalski, A., Blażlak, R. (2014). Współczesne tendencje zarządzania organizacjami poprzez innowacje. Studia Ekonomiczne, 183, cz. 2, 141-150.

Sokol, Ph.K. (1989). EDI: The competitive edge, intertext publications. New York: McGraw-Hill Book Company.

Wielki, J. (2000). Elektroniczny marketing poprzez Internet. Warszawa-Wrocław: Wydawnictwo Naukowe PWN. 


\section{Features of E-Customers as an Important Determinant of the Development of E-Commerce Sector of Electronics/Appliances}

Keywords: e-customer, electronics/appliances sector, electronic commerce

Summary. Customers in the market of electronic commerce are often characterized by homogeneous features, for example low prices and the convenience of online shopping are indicated as the most important advantages of e-commerce. However, in such a turbulent and competitive environment, more and more managers of online trading platforms should focus on actions differentiating the offer. One possibility is a precise knowledge of the behavior, habits and preferences of the target group. Selection of appropriate communication tools personalized for the demographic features of customers and sector can be more efficient operation than traditional forms of marketing. The objective of the article is indicating the differences in behavior and perceiving among customers in the ecommerce sector in relation to basic demographic features. The analysis uses data provided by Opiniac from the survey conducted with the use of online questionnaire.

Translated by Grzegorz Szymański

\section{Cytowanie}

Szymański, G. (2016). Cechy e-klientów istotną determinantą rozwoju branży RTV/AGD sektora e-commerce. Marketing i Zarządzanie, 3 (44), 197-206. 